\title{
Synthesis of Silver Nanoparticles Using Aqueous Extract of Medicinal Plants' (Impatiens balsamina and Lantana camara) Fresh Leaves and Analysis of Antimicrobial Activity
}

\author{
Henry F. Aritonang $(\mathbb{D}$, Harry Koleangan $\mathbb{D}$, and Audy D. Wuntu $(\mathbb{D}$ \\ Physical Chemistry Division, Faculty of Mathematics and Natural Sciences, Sam Ratulangi University, \\ Jalan Kampus Unsrat Kleak, Manado 95115, Indonesia \\ Correspondence should be addressed to Henry F. Aritonang; henryaritonang@unsrat.ac.id
}

Received 29 November 2018; Revised 13 May 2019; Accepted 4 June 2019; Published 1 July 2019

Academic Editor: Todd R. Callaway

Copyright (c) 2019 Henry F. Aritonang et al. This is an open access article distributed under the Creative Commons Attribution License, which permits unrestricted use, distribution, and reproduction in any medium, provided the original work is properly cited.

\begin{abstract}
Plant-mediated synthesis of nanomaterials has been increasingly gaining popularity due to its eco-friendly nature and costeffectiveness. In the present study, we synthesized silver (Ag) nanoparticles using aqueous extracts of fresh leaves of Impatiens balsamina and Lantana camara medicinal plants as bioreducing agents. This method allowed the synthesis of nanoparticles, which was confirmed by ultraviolet-visible (UV-Vis) spectrophotometry and transmission electron microscopy (TEM). UV-Vis spectra and visual observation showed that the color of the fresh leaf extracts of L. camara and I. balsamina turned into grayish brown and brownish yellow, respectively, after treatment with $\mathrm{Ag}$ precursors. In addition, TEM analysis confirmed that $\mathrm{AgNO}_{3}$ solutions for all concentrations produced Ag nanoparticles and their average size was less than $24 \mathrm{~nm}$. Moreover, aqueous leaf extracts of I. balsamina and L. camara were separately tested for their antimicrobial activity against Gram-positive Staphylococcus aureus and Gram-negative Escherichia coli bacteria. The results showed that the bacterial growth was inhibited by the extracts containing Ag nanoparticles. Statistical calculation performed using the Tukey test showed that zones of inhibition for the two bacteria produced by the aqueous leaf extracts of L. camara containing $3 \mathrm{mM}$ and $5 \mathrm{mM} \mathrm{Ag}$ precursors were not significantly different from that by ciprofloxacin as positive control. On the contrary, there was significant difference between the zone of inhibition for E. coli by ciprofloxacin and that by the extracts of I. balsamina leaves containing $3 \mathrm{mM}$ and $5 \mathrm{mM} \mathrm{Ag}$ precursors. A similar result was observed on the zone of inhibition for S. aureus by the extracts of I. balsamina leaves containing $3 \mathrm{mM} \mathrm{Ag} \mathrm{precursor.} \mathrm{It} \mathrm{was} \mathrm{shown}$ that the aqueous extracts of fresh L. camara leaves containing Ag nanoparticles were comparable to ciprofloxacin in inhibiting bacterial growth.
\end{abstract}

\section{Introduction}

Nanoparticles represent a particle with a nanometer size of $1-100 \mathrm{~nm}$. The nanoscale material has new, unique, and superior physical and chemical properties compared to its bulk structure, due to an increase in the ratio of the surface area per volume of the material/particle [1]. The most widely studied nanoparticle materials are metal nanoparticles because they are easier to synthesize. Moreover, these materials have a wide range of applications: detectors, catalysts, surface coating agents, and antibacterial/antimicrobials, among many others. Some of the most studied metallic nanoparticles include silver (Ag) [2, 3], gold (Au) [4], platinum $(\mathrm{Pt})$ [5-7], and palladium $(\mathrm{Pd})$ [8].

$\mathrm{Ag}$ nanoparticle is an interesting metal to be studied, especially in the field of health and medicine. Ag is a strong antibacterial and also toxic to cells. Ag has the ability to damage bacterial cell walls, inhibits bacterial cell growth, and disrupts cell metabolism because of the interaction between Ag ions with macromolecules in cells, such as proteins and deoxyribonucleic acid (DNA). The ion Ag that interacts with the cell prevents protein synthesis, further decreases the membrane permeability, and eventually leads to cell death. The Ag nanoparticles are chemically more reactive than Ag 
in their bulk. Therefore, Ag nanoparticles are indicated to have stronger antibacterial capabilities [9-11].

Ag nanoparticles can be synthesized through several methods, including chemical reduction. Chemical reduction methods are often used because they are easier and economical [12]. This method is done by reducing Ag salts by reducing agents, such as sodium citrate or sodium borohydride [13]. However, the use of chemicals in the synthesis of $\mathrm{Ag}$ nanoparticles results in the adsorption of toxic chemicals (reducing agents and organic solvents) on the surface of the material so that it will have adverse and harmful effects on its application [14]. Therefore, the use of environmentally friendly methods is desirable.

Green synthesis methods for synthesizing nanoparticles using natural products can be used to address the problem by utilizing plants or microorganisms [15]. The utilization of plants in the biosynthesis of nanoparticles involves the content of secondary metabolites as reducing agents [16]. Allegedly, biological agents act as reducers, stabilizers, or both in the process of forming nanoparticles [17]. The biosynthesis of Ag nanoparticles has been carried out by utilizing a number of plants and evaluating the antimicrobial activity, such as ethanol extracts from Cardiospermum halicacabum L. leaves [18], Impatiens balsamina L. leaves [19], and Lantana camara L. fruits [20]. The ethanol extract of I. balsamina and L. camara was obtained from the leaves which were first dried for further analysis of its antimicrobial activity.

I. balsamina and L. camara are one of the most common medicinal plants in Indonesia, especially for wound dressing $[19,21]$. According to Meenu et al. [22], the dry I. balsamina ethanol extract contains chemical compounds such as essential oils, phenols, flavonoids, carbohydrates, proteins, alkaloids, glycosides, iridoid glycosides, phenylethanoids, oligosaccharides, quinine, saponins, steroids, triterpenoids, sesquiterpenoids, and tannins and has antibacterial activity against Staphylococcus epidermidis. The aqueous extract of fresh leaves of I. balsamina and L. camara to synthesize Ag nanoparticles (extract Ag nanoparticles) is important to be investigated mainly because it can be used as a wound medicine that can be packaged in the form of infusions/ fluids. Liquids that use water solvents are much safer for health and the environment than using chemical solvents [23]. Therefore, in this study, we used water as a solvent in medicinal plant extracts.

The present study synthesized Ag nanoparticles using aqueous extracts of fresh leaves of I. balsamina and L. camara and then evaluated its antimicrobial activity, particularly against the growth of Staphylococcus aureus (S. aureus) and Escherichia coli (E. coli) bacteria.

\section{Materials and Methods}

2.1. Chemicals and Plant Material Collection. All the reagents purchased were of analytical grade and used without any further purification. Silver nitrate $\left(\mathrm{AgNO}_{3}\right)$ was purchased from Sigma-Aldrich with a $\geq 99.5 \%$ purity. Fresh leaves of I. balsamina and L. camara were collected from the surroundings of the Bitung region, North Sulawesi, Indonesia
(Figure 1). Distilled water was used for preparing aqueous solutions all over the experiments.

2.2. Preparation of LeafExtract. Aqueous leave extracts were prepared by the following procedure: fresh leaves of I. balsamina were collected and washed with tap water at first, and then the surface was washed under running water with distilled water until no impurities remained. Then, the fresh leaves were cut into small pieces, and $10 \mathrm{~g}$ was weighed and put into a beaker with $100 \mathrm{ml}$ of distilled water. The mixture was heated for 20 minutes at $60^{\circ} \mathrm{C}$ while stirring occasionally and then allowed to cool at room temperature [24]. The mixture was filtered using the Whatman 42 filter paper and then centrifuged at $81 \mathrm{G}$-force for 20 minutes. The extract was stored in the refrigerator for further use to synthesize $\mathrm{Ag}$ nanoparticles from $\mathrm{AgNO}_{3}$ precursor solution. The same process was also done on fresh leaves of L. camara.

2.3. Synthesis of $\mathrm{Ag}$ Nanoparticles. $\mathrm{AgNO}_{3}$ powder was dissolved in distilled water to prepare $10 \mathrm{mM} \mathrm{AgNO}_{3}$ stock solution from which a series of $1 \mathrm{mM}, 2 \mathrm{mM}, 3 \mathrm{mM}, 4 \mathrm{mM}$, and $5 \mathrm{mM} \mathrm{AgNO} 3$ solutions were prepared. The $\mathrm{AgNO}_{3}$ solutions were mixed with the aqueous extract of $I$. balsamina fresh leaves at a ratio of $1: 1(\mathrm{v} / \mathrm{v})$ to a volume of $50 \mathrm{~mL}$ in a flask. The flask was wrapped with an aluminum foil and was then heated in a waterbath at $60^{\circ} \mathrm{C}$ for 5 hours. Furthermore, the mixture was stored in the refrigerator for the antibacterial activity test and further analyzed by using UVVis spectrophotometer and TEM. The same procedure was also carried out on the aqueous extract of L. camara fresh leaves.

2.4. Assay for Antimicrobial Activity of Ag Nanoparticles against Microorganisms. All equipment and growing media were sterilized by autoclaving at $115^{\circ} \mathrm{C}$ and $15 \mathrm{psi}$ for 30 minutes. The antimicrobial activity has been investigated against $S$. aureus as a model for Gram-positive bacteria and E. coli as a model for Gram-negative bacteria. The antimicrobial activity was evaluated by the disc diffusion method. Preparation of the bacteria stock was done to reproduce and rejuvenate bacteria. This was done by inoculating each one inoculation loop pure culture of $E$. coli and $S$. aureus into $5 \mathrm{ml}$ of nutrient agar solution and then incubated at $37^{\circ} \mathrm{C}$ for 24 hours in the incubator. Preparation of test bacteria was carried out by inserting one inoculation loop of cultured bacteria into $5 \mathrm{ml}$ of $0.19 \% \mathrm{NaCl}$ solution. Furthermore, it was vortexed and its turbidity was adjusted to $0.5 \mathrm{McF}$ arland solution turbidity of $\sim 10^{8} \mathrm{CFU} / \mathrm{mL}$ by adding the cultured bacteria [19].

The inhibition method was used in evaluating the antibacterial activity. $20 \mathrm{ml}$ of nutrient agar solution was put into a Petri dish, sterilized for 15 minutes until the nutrient agar solution became solid, and then $0.1 \mathrm{ml}$ of bacterial solution was applied to the nutrient agar growing medium. Thereafter, negative control (distilled water), positive control (Ciprofloxacin), and sample (2 replications) were placed. Next, it was incubated at $37^{\circ} \mathrm{C}$ for 24 hours before the 


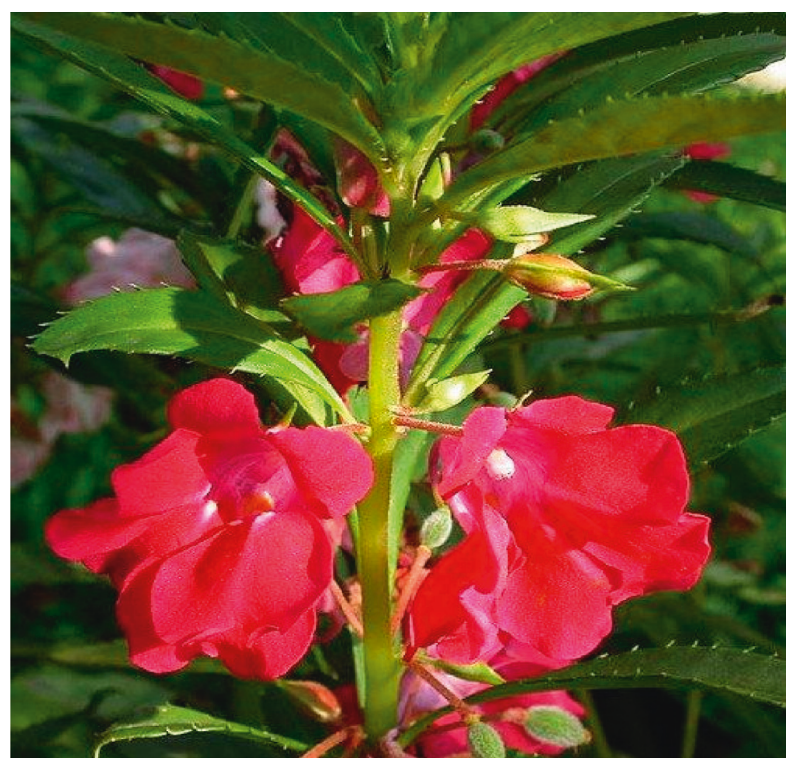

(a)

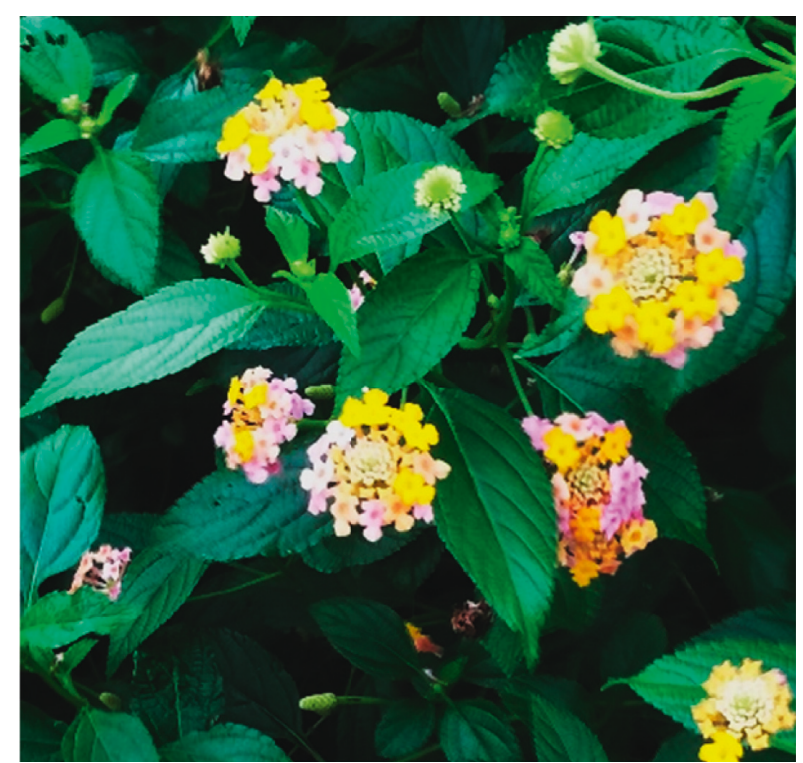

(b)

FIgure 1: Plants: (a) Impatiens balsamina; (b) Lantana camara.

clear zone diameter was measured using the sliding term. To see the ability of each leaf extract containing Ag nanoparticles in inhibiting bacterial growth compared to ciprofloxacin positive control, a statistical analysis was performed using the Tukey test at the $95 \%$ confidence level.

2.5. Characterization of Ag Nanoparticles. The reduction of pure $\mathrm{Ag}^{+}$ions was monitored by measuring the UV-Vis spectrum of the reaction medium after diluting a small aliquot of the sample into distilled water. The color change in the reaction mixture (metal ion solution $+I$. balsamina extract) was recorded through visual observation. UV-Vis spectral analysis was done by using UV-Vis spectrophotometer UV-1800 (Shimadzu) at the wavelength of 200$800 \mathrm{~nm}$. JEOL JEM-1400 Transmission Electron Microscope (TEM), operating at $120 \mathrm{~V}$ and an acceleration voltage of $15 \mathrm{kV}$, was used to analyze the morphology and size of $\mathrm{Ag}$ nanoparticles. For TEM measurements, extract samples containing Ag nanoparticles were dispersed on a copper grid and dried at room temperature. The particle sizes of the $\mathrm{Ag}$ nanoparticles were measured using Image $J$ software. The histogram of the size distribution was established by Origin software.

\section{Results and Discussion}

3.1. UV-Vis Spectra Analysis. The aqueous extract of fresh leaves of I. balsamina and L. camara change their colors when warmed. The I. balsamina extract changes color from colorless to brownish yellow, while L. camara becomes yellowish brown (Figure 2).

This warm extract solution changed color again after adding $\mathrm{AgNO}_{3}$ solution. Color changes are possible because some of the Ag ions begin to be reduced due to the effects of heat and produces $\mathrm{Ag}^{+}$complex. This complex was responsible for changing color from brownish yellow to grayish brown (L. camara), while the I. balsamina extract remained a brownish yellow (Figure $2\left(\mathrm{~A}_{2}\right.$ and $\left.\mathrm{B}_{2}\right)$ ). This color change indicates the formation of $\mathrm{Ag}$ nanoparticles [25].

The Ag nanoparticles synthesized in each extract solution was analyzed using UV-Vis spectroscopy. This was done to determine the characteristics of the peak spectrum of the $\mathrm{Ag}$ nanoparticle wavelength prepared for each different $\mathrm{AgNO}_{3}$ concentrations (1 mM-5 mM) (Figure 3).

The characteristics of Ag nanoparticles normally appear at a wavelength interval of 400-600 nm [26]. UV-Vis spectra of Ag nanoparticles synthesized using the I. balsamina aqueous extract evince the blue shift of the absorption band with increasing $\mathrm{AgNO}_{3}$ concentration. For $1 \mathrm{mM}, 2 \mathrm{mM}, 3 \mathrm{mM}$, $4 \mathrm{mM}$, and $5 \mathrm{mM}$ samples, the absorption peak is centered around $450-420 \mathrm{~nm}$. This information shows that the $\mathrm{Ag}$ nanoparticles have formed in the extract, where the $\mathrm{Ag}^{+}$has been reduced to $\mathrm{Ag}^{0}$. Proteins and all secondary metabolites of extract play a critical role in both the reducing and capping mechanism for nanoparticle formation [25]. The Ag nanoparticles contained in the aqueous extract of the L. camara also exhibit similar characteristics, where the shift of the absorption band with increasing $\mathrm{AgNO}_{3}$ concentrations. However, the shift of the absorption peak was a little narrower than that of the $\mathrm{Ag}$ nanoparticles synthesized with the I. balsamina aqueous extract, where the absorption peak is centered on $450-440 \mathrm{~nm}$. The peak wavelength of Ag nanoparticles in aqueous fresh leaf extracts can be seen in Table 1 .

3.2. TEM Analysis. The size and morphology of Ag nanoparticles synthesized using aqueous extracts of fresh leaves have been evaluated by TEM analysis. The obtained TEM images of the Ag nanoparticles prepared by each leaf extract from I. balsamina and L. camara are shown in Figure 4. 


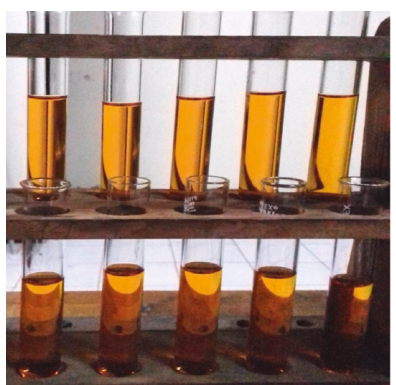

$\mathrm{A}_{1}$

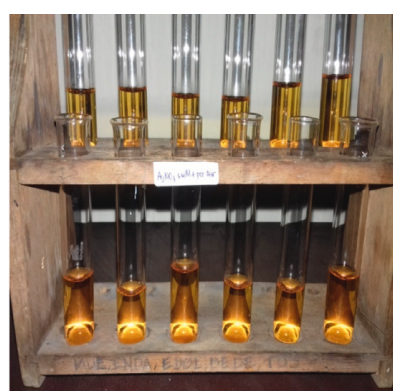

$\mathrm{A}_{2}$

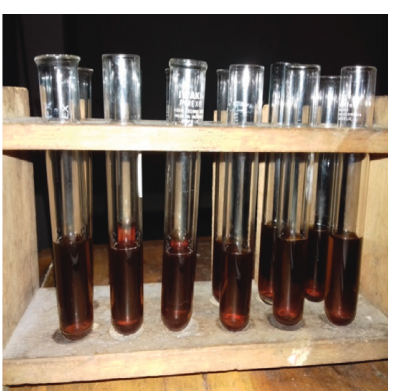

$\mathrm{B}_{1}$

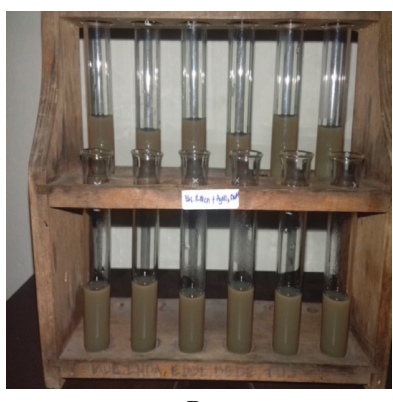

$\mathrm{B}_{2}$

(a)

(b)

Figure 2: Aqueous extract from fresh leaves of (a) I. balsamina and (b) L. camara. Before $\left(\mathrm{A}_{1}\right.$ and $\left.\mathrm{B}_{1}\right)$ and after $\left(\mathrm{A}_{2}\right.$ and $\left.\mathrm{B}_{2}\right)$ the addition of $\mathrm{AgNO}_{3}$ solution.

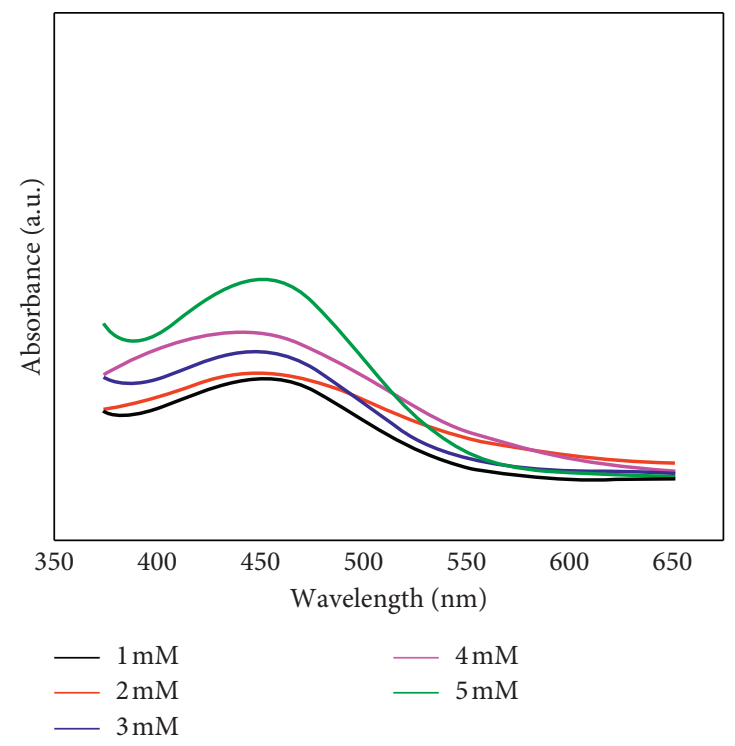

(a)

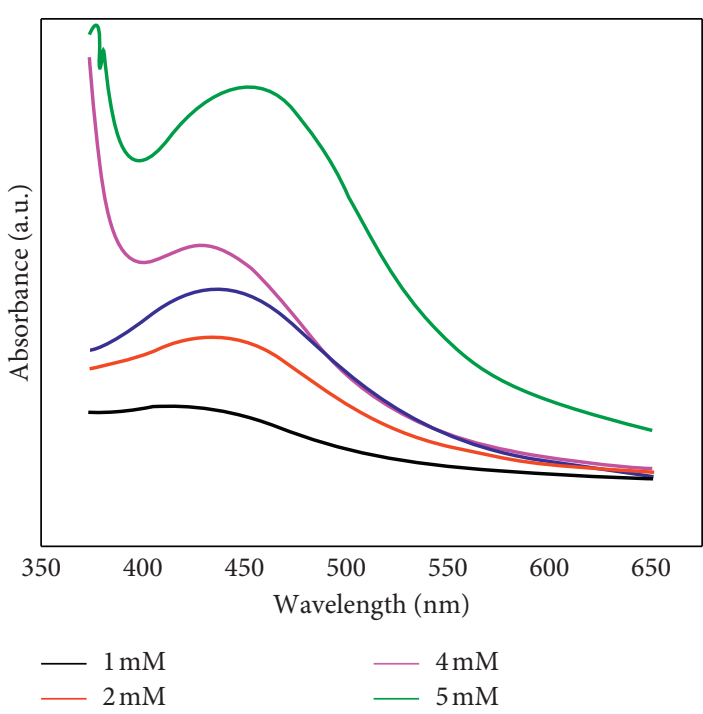

(b)

FIGURE 3: UV-Vis absorbance spectrum of Ag nanoparticles as a function of $\mathrm{AgNO}_{3}$ concentration in aqueous extracts of fresh leaves of (a) I. balsamina and (b) L. camara, respectively.

TABLE 1: Peak wavelength and absorbance of Ag nanoparticles in aqueous extracts of fresh leaves of I. balsamina and L. camara.

\begin{tabular}{lcc}
\hline Concentration $(\mathrm{mM})$ & Wavelength $(\mathrm{nm})$ & Absorbance \\
\hline I. balsamina & 452 & \\
1 & 452 & 0.894 \\
2 & 451 & 0.937 \\
3 & 441 & 1.109 \\
4 & 455 & 1.285 \\
5 & & 1.736 \\
\hline L. camara & 420 & \\
1 & 438 & 0.667 \\
2 & 438 & 1.277 \\
3 & 433 & 1.691 \\
4 & 450 & 2.059 \\
5 & & 3.386 \\
\hline
\end{tabular}

The nanoparticles are quite polydispersed and a layer of the organic material surrounding the synthesized Ag nanoparticles could explain the good dispersion of these nanoparticles in solution. Generally, the Ag nanoparticles synthesized using aqueous extracts are well dispersed although some of them were noted to be agglomerated. Notably, the majority of the particles in the TEM images are not in physical contact with each other but appeared separated by the organic layer. Therefore, TEM images clearly indicate the coating of Ag nanoparticles with an organic layer. The presence of several polyphenolic components including flavonoids and terpenoids facilitated the reduction of $\mathrm{Ag}$ ions and also stabilized the surface of the resultant Ag nanoparticles [25].

The Ag ions quantity influenced the size of the particles. When $\mathrm{AgNO}_{3}$ concentration is increased to $5 \mathrm{mM}$, an obvious change in the size distribution of nanospheres was observed (Table 2).

3.3. Antibacterial Activity Studies. The present study revealed that the tested leaf extracts of I. balsamina and 

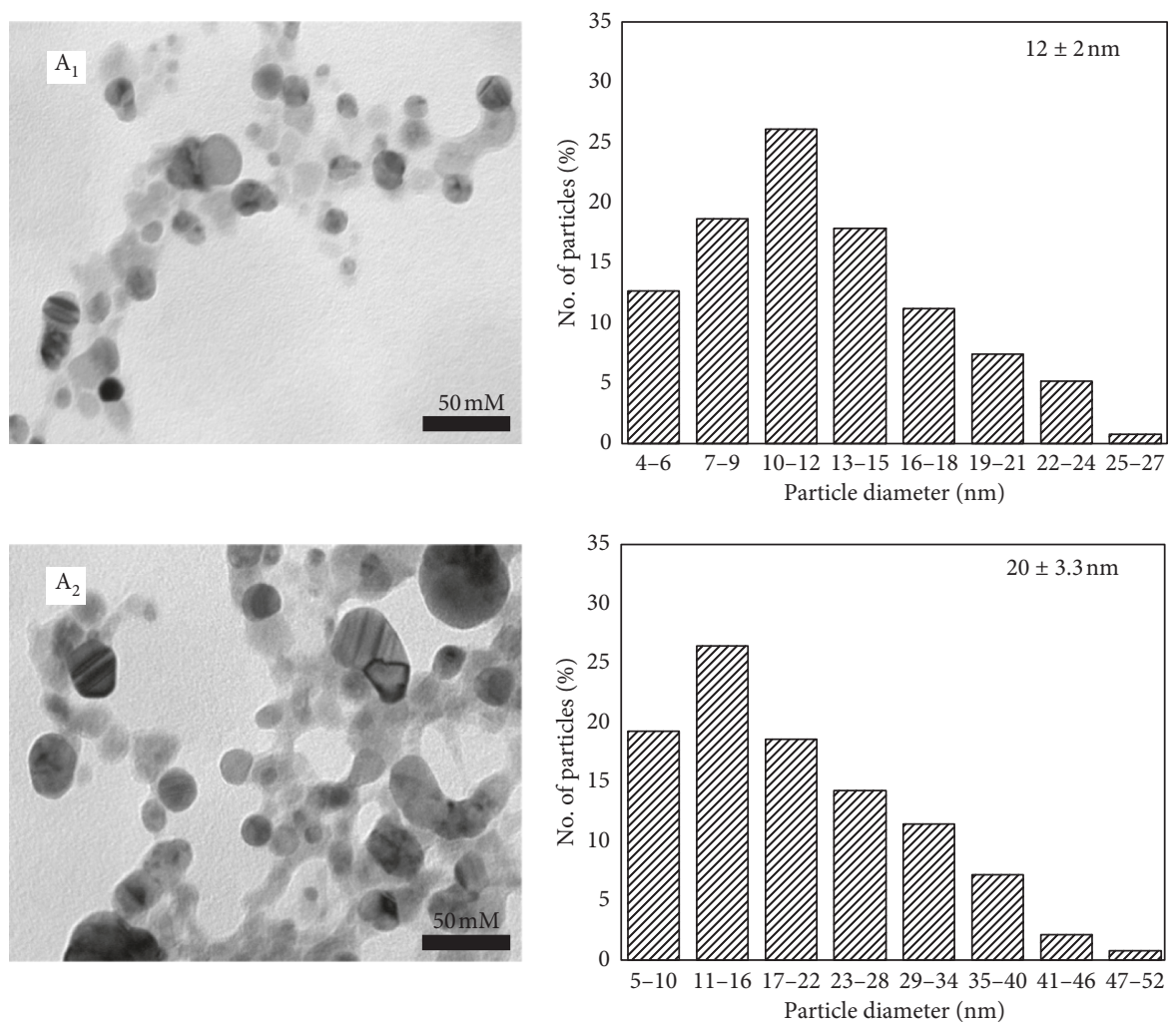

(a)
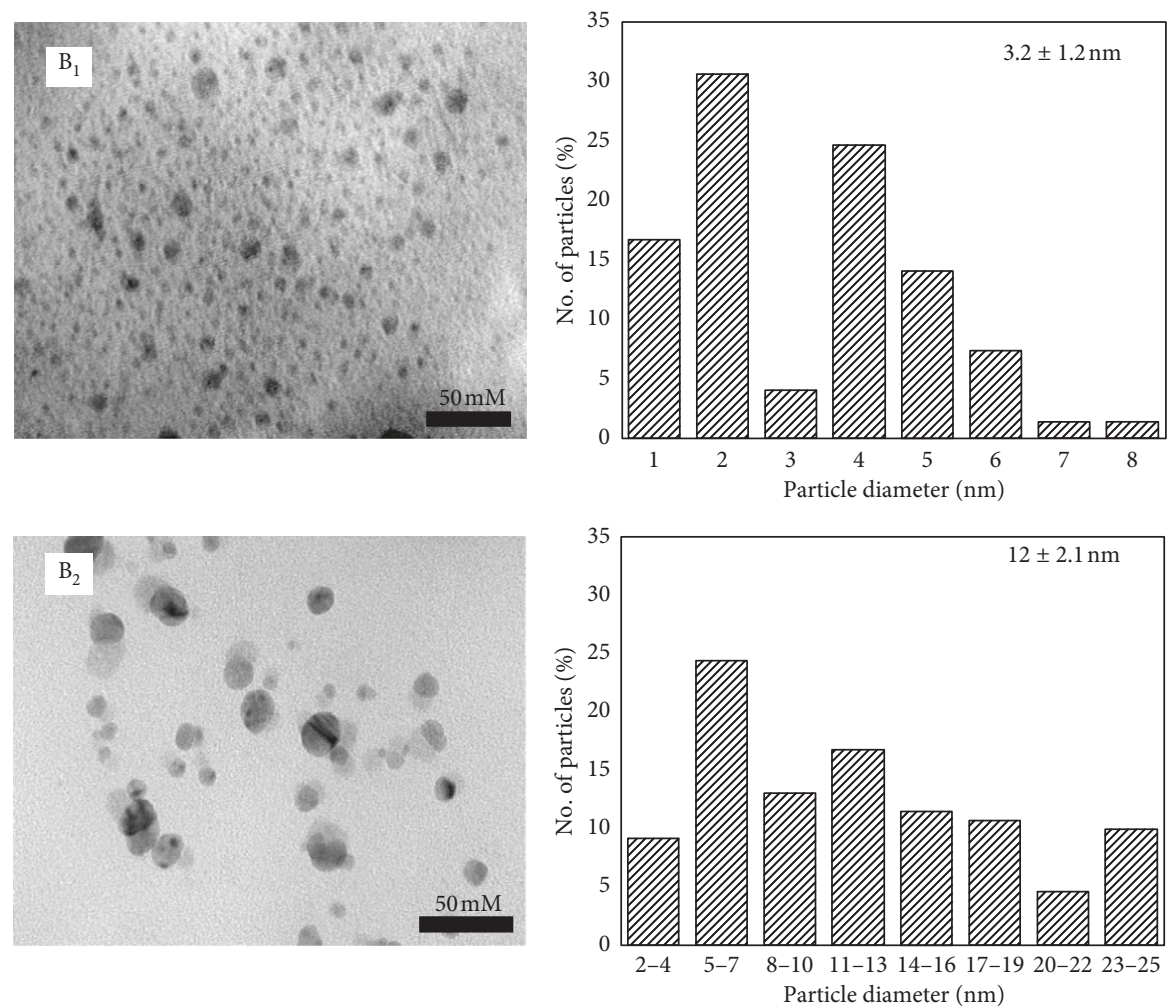

(b)

FIGURE 4: TEM images of Ag nanoparticles in the aqueous extract of (a) I. balsamina and (b) L. camara and their particle-size distribution at different molar concentrations of $\mathrm{AgNO}_{3}: 1 \mathrm{mM}\left(\mathrm{A}_{1}\right.$ and $\left.\mathrm{B}_{1}\right)$ and $5 \mathrm{mM}\left(\mathrm{A}_{2}\right.$ and $\left.\mathrm{B}_{2}\right)$. 
TABLE 2: Size of Ag nanoparticles produced from various concentrations of $\mathrm{AgNO}_{3}$ using aqueous extracts of fresh leaves of $\mathrm{I}$. balsamina and L. camara.

\begin{tabular}{lcc}
\hline Concentration of $\mathrm{AgNO}_{3}$ solution (mM) & Ag nanoparticle size (nm) & L. camara \\
\hline 1 & I. balsamina & $3.2 \pm 1.2$ \\
2 & $12 \pm 2$ & $4 \pm 1$ \\
3 & $15 \pm 2.1$ & $6 \pm 1.1$ \\
4 & $17 \pm 2.2$ & $10 \pm 1.3$ \\
5 & $19 \pm 2.5$ & $12 \pm 2.1$ \\
\hline
\end{tabular}
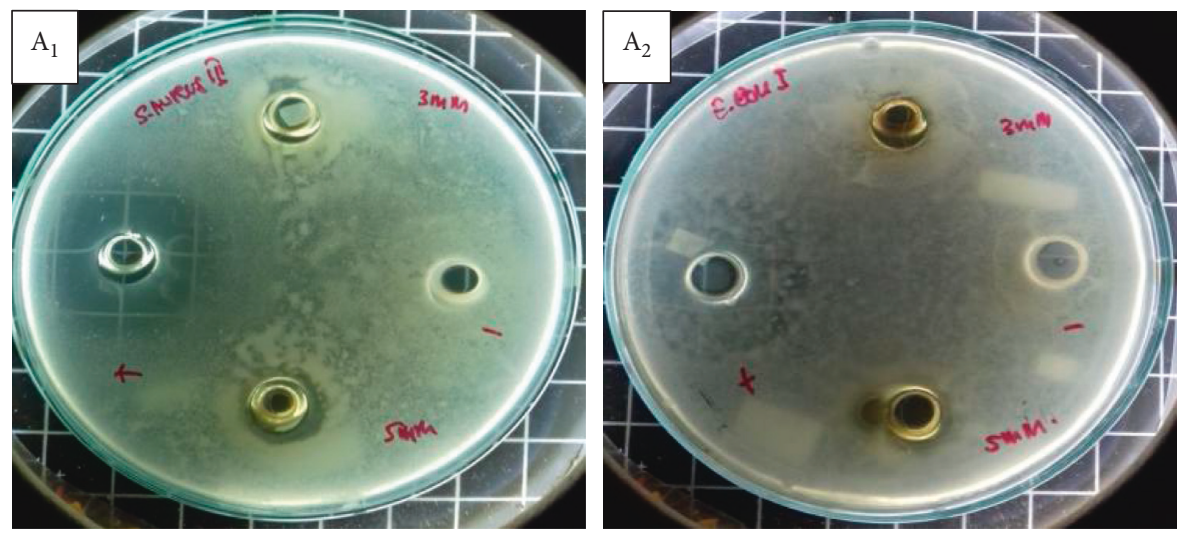

(a)
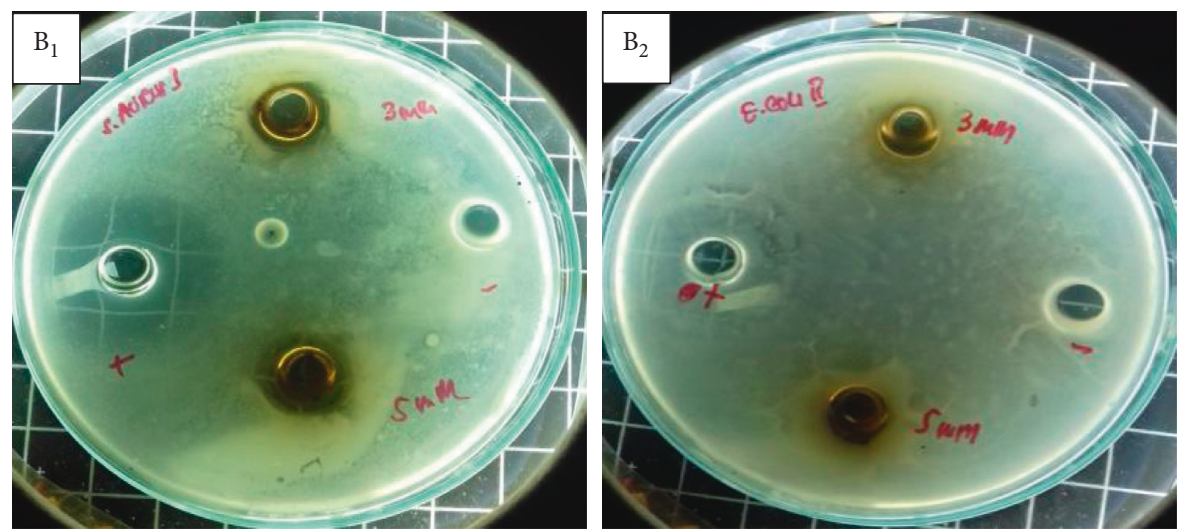

(b)

FIgURE 5: Antibacterial activity of Ag nanoparticles synthesized using aqueous leaf extracts of I. balsamina (a) and L. camara (b) against Gram-positive $S$. aureus $\left(\mathrm{A}_{1}\right.$ and $\left.\mathrm{B}_{1}\right)$ and Gram-negative E. coli bacteria $\left(\mathrm{A}_{2}\right.$ and $\left.\mathrm{B}_{2}\right)$.

L. camara medicinal plants showed potent antibacterial activity against two bacterial strains: Gram-positive S. aureus and Gram-negative E. coli. Aqueous extracts of I. balsamina and L. camara containing Ag nanoparticles showed activity in all Ag concentrations tested against all bacteria (Figure 5).

Antibacterial activity was shown by an inhibition zone which was characterized by a clear zone between the wells (containing samples) and a certain distance. Formation of inhibition zones around the wells shows bacterial sensitivity to antibacterial and antibiotic ingredients (which are used as positive controls). The positive control used in the well was a ciprofloxacin $500 \mathrm{mg}$ solution and functioned as a control of the test solution by comparing the diameter of the inhibition zone formed. On the contrary, distilled water as negative control was used to determine the effect of solvents in the test solution on the growth of $S$. aureus and E. coli bacteria. It was clear that it was the extracts containing Ag nanoparticles that had the antibacterial activity, not the solvent.

The diameter of inhibition zones formed for each concentration of the $\mathrm{AgNO}_{3}$ precursor added to the aqueous extracts of fresh leaves of I. balsamina and L. camara medicinal plants in synthesizing Ag nanoparticles is presented in Table 3.

Table 3 shows that the antibacterial activity against S. aureus was increased, which was indicated by an increase in the inhibition zone diameter from $11.03 \mathrm{~mm}$ to $13.8 \mathrm{~mm}$, with the increasing Ag concentration in I. balsamina extract. However, the opposite result was shown by E. coli, which was from $10.2 \mathrm{~mm}$ to $8.9 \mathrm{~mm}$. The same was true for $\mathrm{Ag}$ nanoparticles in $L$. camara aqueous extracts which were 
TABLE 3: Antibacterial activity of Ag nanoparticles synthesized using various concentrations of $\mathrm{AgNO}_{3}$ precursors and aqueous extracts of fresh leaves of I. balsamina and L. camara.

\begin{tabular}{|c|c|c|c|c|c|c|}
\hline \multirow{2}{*}{ Plants } & \multirow{2}{*}{\multicolumn{2}{|c|}{$\begin{array}{c}{\left[\mathrm{AgNO}_{3}\right](\mathrm{mM}) /} \\
\text { replication }\end{array}$}} & \multicolumn{4}{|c|}{ Zone of inhibition (mm) } \\
\hline & & & S. aureus & Positive control & E. coli & Positive control \\
\hline \multirow{8}{*}{ I. balsamina } & 3 & 1 & 11.3 & 18.2 & 14.3 & 17.8 \\
\hline & & 2 & 12.3 & 21.2 & 7.8 & 20.7 \\
\hline & & 3 & 9.5 & 19.7 & 8.5 & 20 \\
\hline & Average & & $11.03^{\mathrm{a}}$ & $19.7^{\mathrm{b}}$ & $10.2^{\mathrm{c}}$ & $19.5^{\mathrm{d}}$ \\
\hline & 5 & 1 & 20 & 19.7 & 10.3 & 19.6 \\
\hline & & 2 & 10.5 & 19.8 & 7.3 & 19.4 \\
\hline & & 3 & 11 & 19.6 & 9 & 19.5 \\
\hline & Average & & 13.8 & 19.7 & $8.9^{\mathrm{e}}$ & $19.5^{\mathrm{f}}$ \\
\hline \multirow{8}{*}{ L. camara } & 3 & 1 & 12.8 & 18.1 & 20.5 & 18 \\
\hline & & 2 & 14.5 & 20.9 & 15.3 & 21 \\
\hline & & 3 & 14.5 & 20 & 17.3 & 19.8 \\
\hline & Average & & 13.9 & 19.7 & 17.7 & 19.6 \\
\hline & 5 & 1 & 13 & 19.6 & 15.3 & 19.4 \\
\hline & & 2 & 20 & 19.8 & 16.5 & 19.7 \\
\hline & & 3 & 14.3 & 19.8 & 14.5 & 19.8 \\
\hline & Average & & 15.8 & 19.73 & 15.4 & 19.63 \\
\hline
\end{tabular}

Positive control = ciprofloxacin; values indicated with "a" are significantly different from values indicated with "b"; values indicated with "c" are significantly different from values indicated with " $\mathrm{d}$ "; values indicated with "e" are significantly different from values indicated with " $\mathrm{f}$ ".

from $13.9 \mathrm{~mm}$ to $15.8 \mathrm{~mm}$ and $17.7 \mathrm{~mm}$ to $15.4 \mathrm{~mm}$ for $S$. aureus and E. coli, respectively. While the distilled water negative control did not show inhibition zone for all treatments, ciprofloxacin positive control showed similar inhibition zone diameter, which average above $19 \mathrm{~mm}$, for the two bacteria with the increasing Ag concentration in leaves extracts of the two plants.

However, based on the results of statistical analysis, it was shown that only three treatments were significantly different than the positive controls. The variables were aqueous extracts of $I$. balsamina leaves containing Ag nanoparticles $(3 \mathrm{mM})$ against $S$. aureus and E. coli bacteria and aqueous extracts of $I$. balsamina leaves containing Ag nanoparticles $(5 \mathrm{mM})$ against $E$. coli bacteria.

This information was supported by data that the average size of Ag nanoparticles synthesized using L. camara extract was relatively smaller than that using the extract of $I$. balsamina. The results of this study were also supported by previous studies that the small size of Ag nanoparticles makes these particles easier to penetrate the outer wall of bacteria, enter the body, destroy the respiratory chain, and thus inhibit cell respiration, causing bacterial death $[27,28]$. Regarding the inhibition zone, the antibacterial activity of Ag nanoparticles synthesized in this study was categorized into strong inhibitory activity (inhibition zone of $10-19 \mathrm{~mm}$ ) according to Davis and Stout [29].

\section{Conclusions}

Medicinal plants, namely, aqueous extracts of fresh leaves of I. balsamina and L. camara, can be used as bioreduction agents to produce Ag nanoparticles. The formation of Ag nanoparticles in the extract was observed by the color change of I. balsamina extract into brownish yellow while of L. camara extract into grayish brown. Color changes that occur indicate that Ag particles have formed. The Ag particles produced had an increased size due to the increased concentration of $\mathrm{AgNO}_{3}$ solution, but the average size is still in nanometer. Ag nanoparticles contained in the extract were able to inhibit the growth of $S$. aureus and E. coli bacteria, and the best antibacterial activity was exhibited by the L. camara extract containing Ag nanoparticles.

\section{Data Availability}

The data used to support the findings of this study are available from the corresponding author upon request.

\section{Conflicts of Interest}

The authors declare that there are no conflicts of interest.

\section{Acknowledgments}

The authors would like to thank Sam Ratulangi University in Manado, North Sulawesi, Indonesia, for their financial support through the Non-Tax Revenue (PNBP) fund with the contract number 656/UN12.13/LT/2018.

\section{References}

[1] B. L. Cushing, V. L. Kolesnichenko, and C. J. O’Connor, "Recent advances in the liquid-phase syntheses of inorganic nanoparticles," Chemical Reviews, vol. 104, no. 9, pp. 38933946, 2004.

[2] B. Ajitha, Y. Ashok Kumar Reddy, and P. Sreedhara Reddy, "Green synthesis and characterization of silver nanoparticles using Lantana camara leaf extract," Materials Science and Engineering: C, vol. 49, pp. 373-381, 2015.

[3] A. Feng, S. Wu, S. Chen, H. Zhang, W. Shao, and Z. Xiao, "Synthesis of silver nanoparticles with tunable morphologies via a reverse nano-emulsion route," Materials Transactions, vol. 54, no. 7, pp. 1145-1148, 2013. 
[4] M. Moreira dos Santos, M. João Queiroz, and P. V. Baptista, "Enhancement of antibiotic effect via gold:silver-alloy nanoparticles," Journal of Nanoparticle Research, vol. 14, no. 5, pp. 859-866, 2012.

[5] H. F. Aritonang, D. Onggo, C. Ciptati, and C. L. Radiman, "Synthesis of platinum nanoparticles from $\mathrm{K}_{2} \mathrm{PtCl}_{4}$ solution using bacterial cellulose matrix," Journal of Nanoparticles, vol. 2014, Article ID 285954, 6 pages, 2014.

[6] H. F. Aritonang, D. Onggo, C. Ciptati, and C. L. Radiman, "Insertion of platinum particles in bacterial cellulose membranes from $\mathrm{PtCl}_{4}$ and $\mathrm{H}_{2} \mathrm{PtCl}_{6}$ precursors," Macromolecular Symposia, vol. 353, no. 1, pp. 55-56, 2015.

[7] H. F. Aritonang, V. S. Kamu, C. Ciptati, D. Onggo, and C. L. Radiman, "Performance of platinum nanoparticles/ multiwalled carbon nanotubes/bacterial cellulose composite as anode catalyst for proton exchange membrane fuel cells," Bulletin of Chemical Reaction Engineering \& Catalysis, vol. 12, no. 2, pp. 287-292, 2017.

[8] R. W. Raut, A. S. M. Haroon, Y. S. Malaghe, B. T. Nikan, and S. B. Kashid, "Rapid biosynthesis of platinum and palladium metal nanoparticles using root extract of Asparagus racemosus Linn.," Advanced Materials Letters, vol. 4, no. 8, pp. 650-654, 2013.

[9] R. Vazquez-Muñoz, B. Borrego, K. Juárez-Moreno et al., "Toxicity of silver nanoparticles in biological systems: does the complexity of biological systems matter?," Toxicology Letters, vol. 276, pp. 11-20, 2017.

[10] J. Kim, S. Kwon, and E. Ostler, "Antimicrobial effect of silverimpregnated cellulose: potential for antimicrobial therapy," Journal of Biological Engineering, vol. 3, no. 1, pp. 20-28, 2009.

[11] M. Rai, A. Yadav, and A. Gade, "Silver nanoparticles as a new generation of antimicrobials," Biotechnology Advances, vol. 27, no. 1, pp. 76-83, 2009.

[12] A. Zielińska, E. Skwarek, A. Zaleska, M. Gazda, and J. Hupka, "Preparation of silver nanoparticles with controlled particles size," Procedia Chemistry, vol. 1, no. 2, pp. 1560-1566, 2009.

[13] I. Sondik and S. Salopek-Sondi, "Silver nanoperticles as antimicrobial agent: a case study on E. Coli as a model for gramnegative bacteria," Journal of Colloid and Interface Science, vol. 275 , no. 4, pp. 177-182, 2004.

[14] A. Singh, D. Jain, M. K. Upadhyay, N. Khandelwal, and D. H. N. Verma, "Green synthesis of silver nanoparticles using Argenone mexicana leaf extract and their charactrization," Digest Journal of Nanomaterials and Biostructures, vol. 6, no. 1, pp. 483-489, 2010.

[15] S. D. Solomon, M. Bahadory, A. V. Jeyarajasingam, S. A. Rutkowsky, and C. Boritz, "Synthesis and study of silver nanoparticles," Journal of Chemical Education, vol. 84, no. 2, pp. 322-325, 2007.

[16] L. Jirovetz, G. Buchbauer, M. P. Shafi, and N. K. Leela, "Analysis of the essential oils of the leaves, stems, rhizomes and roots of the medicinal plant Alpinia galanga from southern India," Acta Pharmaceutica, vol. 53, no. 2, pp. 73-82, 2003.

[17] S. P. Chandran, M. Chaudhary, R. Pasricha, A. Ahmad, and M. Sastry, "Synthesis of gold nanotriangles and silver nanoparticles using aloe vera plant extract," Biotechnology Progress, vol. 22, no. 2, pp. 577-583, 2006.

[18] S. S. Mahipal, M. Manokari, N. Kannan, J. Revathi, and R. Latha, "Synthesis of silver nanoparticles using Cardiospermum halicacabum L. leaf extract and their characterization," Journal of Phytopharmacology, vol. 2, no. 5, pp. 15-20, 2013.
[19] S.-N. Kang, Y.-M. Goo, M.-R. Yang et al., "Antioxidant and antimicrobial activities of ethanol extract from the stem and leaf of Impatiens balsamina L. (Balsaminaceae) at different harvest times," Molecules, vol. 18, no. 6, pp. 6356-6365, 2013.

[20] M. L. Edy Parwanto, H. Senjaya, and H. Jaya Edy, "Formulasi salep antibakteri ekstrak etanol daun tembelekan (Lantana camara L.)," Pharmacon Jurnal Ilmiah Farmasi-UNSRAT, vol. 2, no. 3, 2013.

[21] J. Kinho, D. I. D Arini, J. Halawane et al., Tumbuhan Obat Tradisional Di Sulawesi Utara, Penerbit Balai Penelitian Kehutanan, Kota Manado, Indonesia, 2011, ISBN 978-60298144-1-5.

[22] B. Meenu, E. D. Neeraja, R. Greeshma, and V. Alexeyena, "Impatiens balsamina: an overview," Journal of Chemical and Pharmaceutical Research, vol. 7, no. 9, pp. 16-21, 2015.

[23] F. P. Byrne, S. Jin, G. Paggiola et al., "Tools and techniques for solvent selection: green solvent selection guides," Sustainable Chemical Processes, vol. 4, no. 1, pp. 1-24, 2016.

[24] J. Das, M. Paul Das, and P. Velusamy, "Sesbania grandiflora leaf extract mediated green synthesis of antibacterial silver nanoparticles against selected human pathogens," Spectrochimica Acta Part A: Molecular and Biomolecular Spectroscopy, vol. 104, pp. 265-270, 2013.

[25] G. Marslin, K. Siram, Q. Maqbool et al., "Secondary metabolites in the green synthesis of metallic nanoparticles," Materials, vol. 11, no. 6, p. 940, 2018.

[26] R. Vasireddy, R. Paul, and A. Krishna Mitra, "Green synthesis of silver nanoparticles and the study of optical properties," Nanomaterials and Nanotechnology, vol. 2, p. 8, 2012.

[27] N. Skandalis, A. Dimopoulou, A. Georgopoulou et al., "The effect of silver nanoparticles size, produced using plant extract from Arbutus unedo, on their antibacterial efficacy," Nanomaterials, vol. 7, no. 7, p. 178, 2017.

[28] G. Franci, A. Falanga, S. Galdiero et al., "Silver nanoparticles as potential antibacterial agents," Molecules, vol. 20, no. 5, pp. 8856-8874, 2015.

[29] W. W. Davis and T. R. Stout, "Disc plate method of microbiological antibiotic essay," Journal of Microbiology, vol. 22, no. 4, pp. 666-670, 1971. 


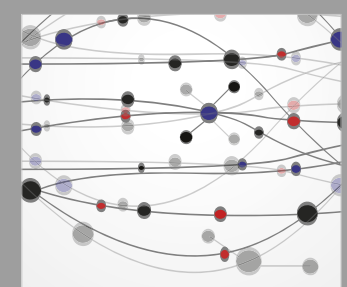

The Scientific World Journal
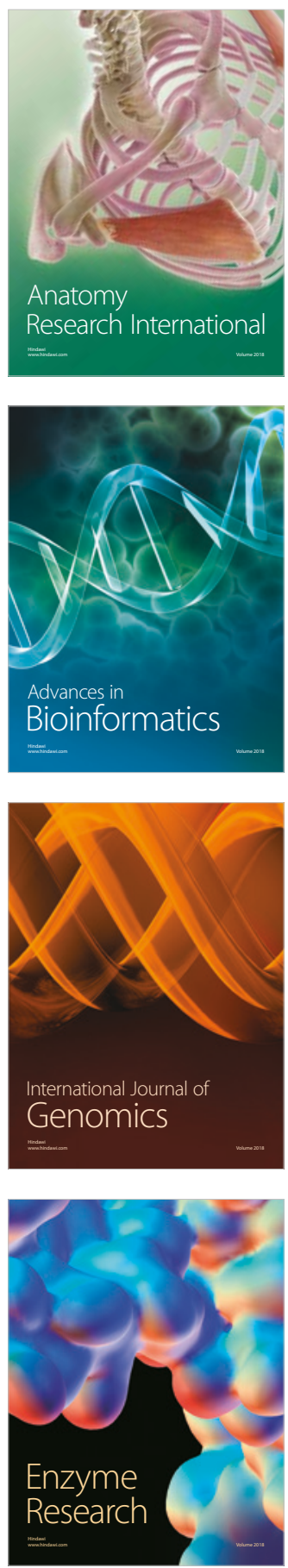
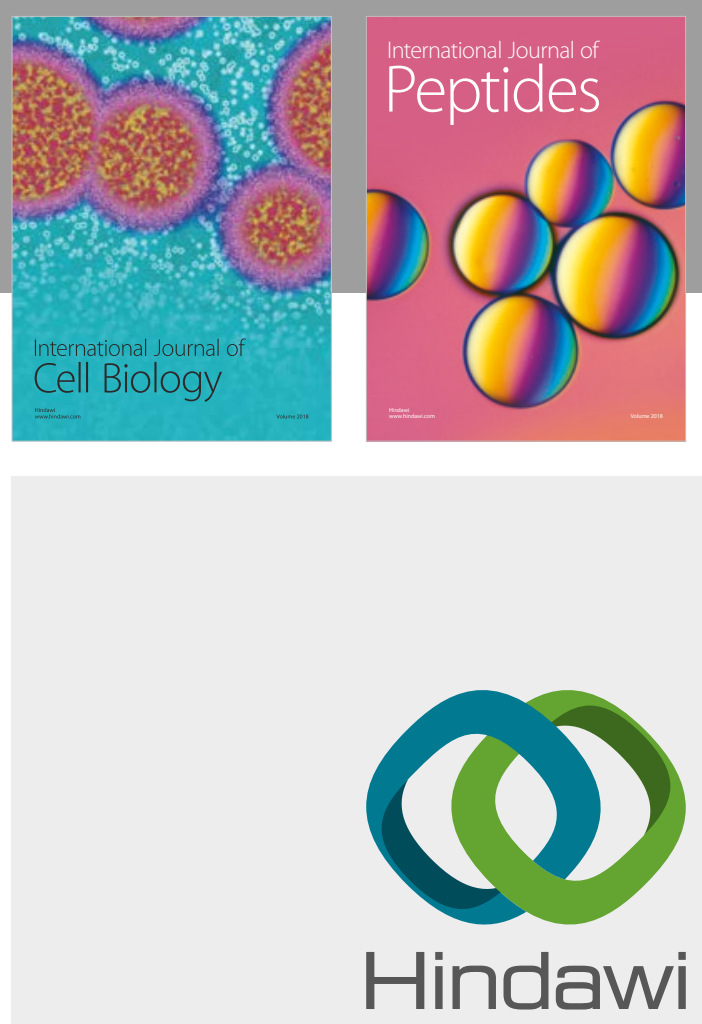

Submit your manuscripts at

www.hindawi.com
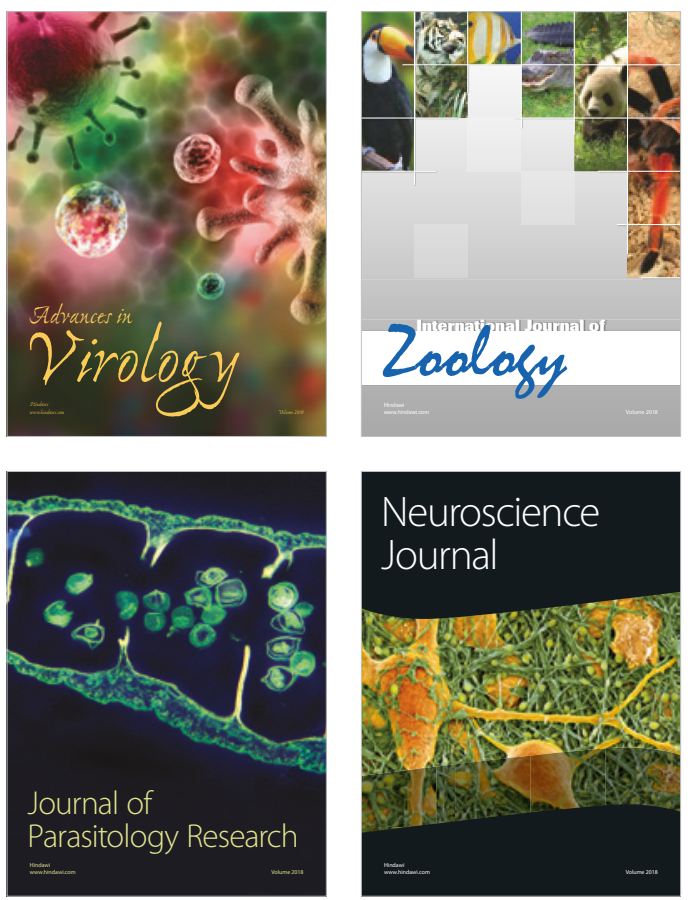
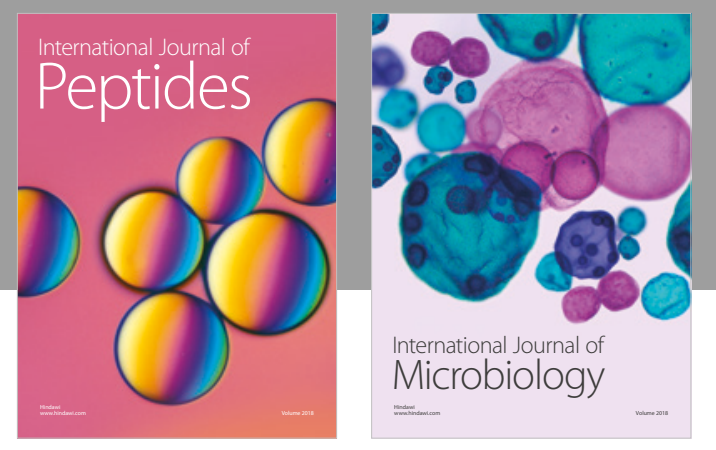

nternational Journal of Microbiology
Journal of
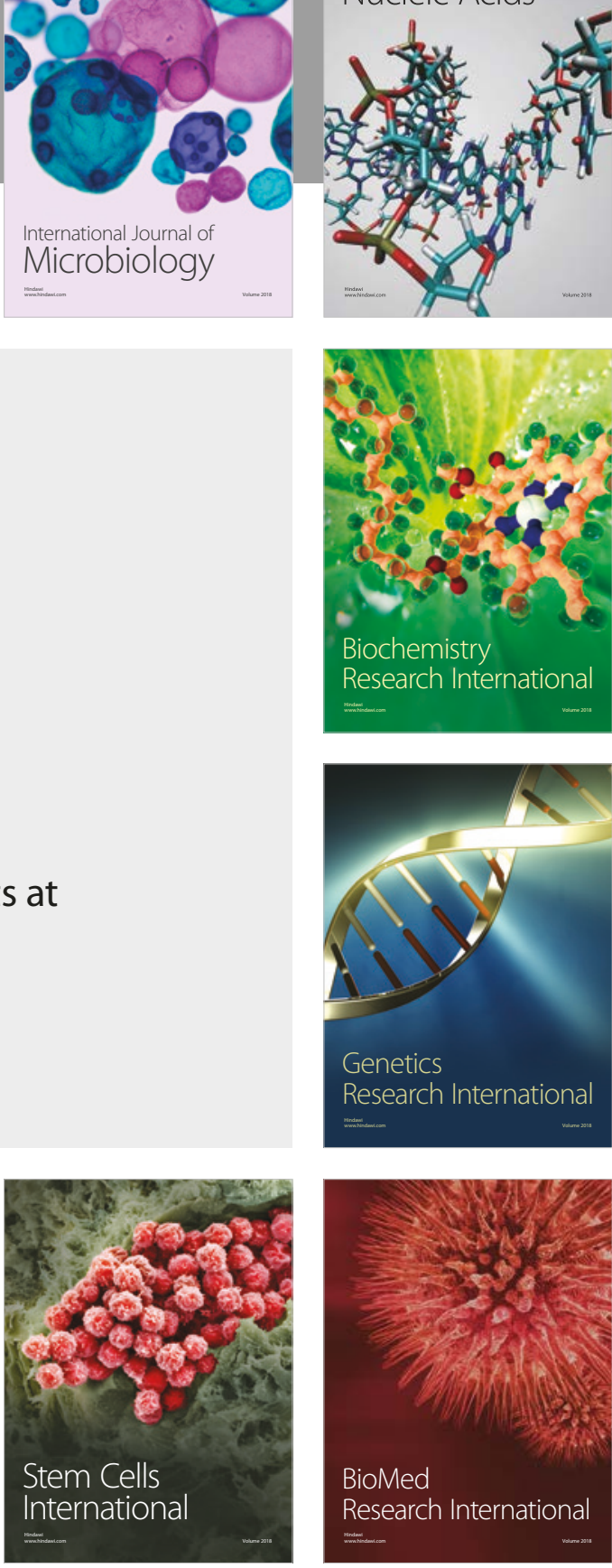
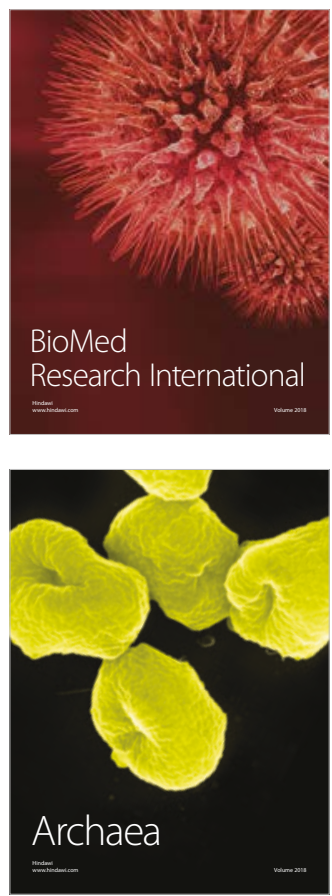